\title{
DIÁSPORAS: QUESTÕES E PERSPECTIVAS SOBRE OS ESTUDOS DE IMIGRANTES E REFUGIADOS NOS SÉCULOS XX E XXI
}

\author{
Diasporas: problems and perspectives of research on \\ immigrants and refugees in the 20th and 21st centuries \\ Diásporas: problemas y perspectivas sobre los estudios de \\ inmigrantes y refugiados en los siglos $X X$ y XXI
}

Helen Rotta

Pontifícia Universidade Católica do Rio Grande do Sul, Porto Alegre, RS, Brasil.

Vinícius Liebel ${ }^{2}$

Universidade Federal do Rio de Janeiro, Rio de Janeiro, RJ, Brasil.

\section{Resumo}

Diante da crise dos refugiados observada na Europa nos últimos anos, a ideia de diáspora (ou das diásporas) entrou novamente em evidência. Produções acadêmicas e pesquisas sobre a temática ganharam visibilidade, em um processo que, apesar dos acontecimentos recentes, já vem em crescente há décadas. Torna-se, assim, uma necessidade a observação do estado da arte, uma discussão sobre os avanços e os limites

\footnotetext{
1 Historiadora, doutoranda em História pela Pontifícia Universidade Católica do RS (PUCRS), bolsista Capes. ORCID: https://orcid.org/oooo-0002-1746-3517. E-mail: helen.rotta@acad.pucrs.br 2 Professor Adjunto de História Contemporânea, Instituto de História da Universidade Federal do Rio de Janeiro (UFRJ). Historiador, Doutor em Ciência Política pela Freie Universität Berlim (FU-Berlin). Pesquisador associado ao Núcleo Interdisciplinar de Estudos Judaicos e Árabes (NIEJ-UFRJ) e ao Núcleo de Estudos Contemporâneos (NEC-UFF). ORCID: https://orcid. org/o000-0002-3188-6567. E-mail: liebel@daad-alumni.de
} 
que a abordagem das diásporas encontrou nesses últimos anos e, particularmente, as possibilidades que ela nos reserva. Epistemologicamente, portanto, é necessário lançar uma visão crítica sobre as principais abordagens e sobre os resultados das pesquisas sobre as diásporas, levantando debates e perspectivas e avanços nesse campo. Críticas aos binarismos e os debates de gênero têm questionado as concepções científicas homogêneas, principalmente, como será abordado neste artigo, o estudo das mulheres em trânsitos diaspóricos, que rompe com a invisibilidade de minorias nesse processo e subverte o paradigma da igualdade. O impacto e as reflexões que a temática nos abre também se tornam objeto deste ensaio, que não pretende esgotar a produção acerca das diásporas, mas olhar para esses trânsitos a partir de novas perspectivas.

Palavras-chave: Diáspora. Historiografia. Refugiados. Migrantes.

\begin{abstract}
With the Europe's refugee crisis of recent years, the idea of diaspora (or diasporas) has come to the fore again. Academic productions and research on the subject have now renewed visibility in a process that, despite recent events, has been growing for decades. It thus becomes a necessity to observe the state of the art and to discuss the advances and limits that the diasporas approach has faced in recent years and, particularly, the possibilities that it still has. Therefore, it is necessary to cast a critical view on the main approaches and on the results of diasporic research, raising debates, perspectives and advances in this field. It is necessary to take a critical epistemological view of the main approaches and results of the research on diasporas, raising different debates and perspectives in this field. The criticism facing binarisms and gender debates have questioned homogeneous scientific conceptions especially, as this essay shows, the study of women in diasporic transits, which questions the invisibility of minorities in this process and subverts the paradigm of equality. The impact and reflections that are opened by the theme are also object of this essay, which, not intending to exhaust the production (especially the historiographic one) on diasporas, presents and revisits the hard core of these researches.
\end{abstract}

Keywords: Diasporas. Historiography. Refugees. Migrants.

\title{
Resumen
}

Frente a la crisis de refugiados observada en Europa en los últimos años, la idea de la diáspora (o diásporas) ha vuelto a surgir. Las producciones académicas y la investigación sobre el tema han ganado visibilidad, en un proceso que, a pesar de los recientes 
acontecimientos, ha crecido durante las últimas décadas. Por lo tanto, se convierte en una necesidad observar el estado del arte, una discusión sobre los avances y límites que el enfoque de la diáspora ha encontrado en los últimos años y, en particular, las posibilidades que nos tiene reservadas. Epistemológicamente, por lo tanto, es necesario emitir una visión crítica sobre los principales enfoques y los resultados de la investigación diaspórica, generando debates y perspectivas y avances en este campo. Las críticas a los binarismos y los debates de género han cuestionado las concepciones científicas homogéneas, principalmente, cómo se abordarán en este artículo, el estudio de las mujeres en tránsitos diásporos, que rompe con la invisibilidad de las minorías en este proceso y subvertente el paradigma de la igualdad. El impacto y las reflexiones que el tema nos abre también se convierten en el objeto de este ensayo, que sin pretender agotar la producción (especialmente la historiográfica) sobre las diásporas, presenta y revisita el núcleo duro de estas investigaciones.

Palabras clave: Diáspora. Historiografía. Refugiados. Inmigrantes.

\section{Introdução}

Poucos temas foram tão trabalhados e discutidos na Academia nos últimos anos, enquanto conceito e objeto, quanto as diásporas. É possível mesmo localizar em meados dos anos 1980 uma "virada diaspórica" nas Humanidades, que passa de um tema de interesse marginal para o centro de centenas de trabalhos anuais no século XXI. A razão para esse interesse parece clara: 0 século $X X$ teve em toda a sua extensão a presença permanente do migrante e do refugiado, desde os deslocamentos do início do século, especialmente partindo da Europa, em movimentos internos e extraeuropeus, passando pelos êxodos provocados pela Primeira e pela Segunda Guerra Mundial, as ondas descoloniais, chegando até as migrações provocadas pela queda do socialismo e da Guerra Fria. Estima-se que cerca de 33 milhões de pessoas viviam fora de seus países de origem em 1910, número que chegou a 175 milhões em 2000, ou seja, enquanto a população do planeta triplicou nesse período, o número de pessoas que vivem em países outros que aquele onde nasceram aumentou seis vezes (ZLOTNIK, 2001, p. 227).

Epistemologicamente, o uso de teorias científicas tradicionais já não dá mais conta de perceber as demandas de novas agências sociais envol- 
vidas no processo, principalmente, as que dizem respeito os estudos de gênero, de modo que o desfecho das novas formas de se movimentar não corresponde a narrativas de igualdade e homogeneidade construídas até então. Donna Haraway (2009) aponta a necessidade de se compreender a forma como essas narrativas foram, são e serão sempre situadas, ou seja, são marcadamente concebidas por uma relação de gênero que lhes é inerente e que tem como consequências brutais processos de invisibilidades de agentes em condição de subalternidade nesse processo.

Os sentidos de se pensar, portanto, novas abordagens epistêmicas para o conceito de diáspora se tornam fundamental. Sobretudo assumindo a reflexão de que novas formas de compreender a ciência, descentralizada, abandonando os constructos rígidos do eurocentrismo como únicas maneiras do pensar, são possíveis e profícuas no âmbito da compreensão de processos que envolvem agentes do mundo todo e que se movimentam por contextos, dinâmicas e temporalidades distintas.

No que diz respeito ao problema do próprio conceito e uso do termo diáspora, torna-se desnecessário dizer que o interesse continua a ser alimentado constantemente em nosso século com os deslocamentos provocados por guerras e por catástrofes humanitárias. Isso resulta, por um lado, no aumento do interesse no tema da diáspora na Academia, fomentado, em um primeiro momento, pelo fortalecimento da identidade afro-americana nos Estados Unidos, advinda do movimento Black Power, como Tölölyan (2017, p. 26) argumenta, e, em seguida, pela diáspora europeia resultante da queda do bloco socialista; por outro lado, estimula também uma ampliação dos usos e dos significados do conceito.

O foco não está mais apenas no estudo de comunidades étnicas e/ou nacionais, mas também a dispersão de comunidades linguísticas, religiosas e culturais tem sido analisada sob o signo da diáspora, uma expansão temática, conceitual e geográfica que leva, nas palavras de Rogers Brubaker (2005), a uma diáspora da diáspora. Não é possível, entretanto, dar unidade a esses modelos; suas características culturais e conjunturais não permitem que sejam reconhecidos e enquadrados em estruturas narrativas generalistas. 
Além disso, os estudos compreendem uma série de "papeis diaspóricos" exercidos pelos atores, que vão de escravos a trabalhadores regularizados, de exilados a refugiados. Nesse amplo espectro, não há modelo ou enquadramento possível. Nesse sentido, cabe refletir sobre a especificidade da diáspora: cada caso necessita de uma análise mais detalhada, pois, a sua experiência é aquilo que modula as suas principais formas de operar.

Ainda assim, há que se considerar uma série de problemáticas epistemológicas que giram em torno desses estudos: muitos se dedicam aos processos de "assimilação cultural"; outros estão focados em entender as motivações causais ou receptoras desses agentes sociais, enquanto uma outra parcela considerável se concentra nos aspectos jurídicos da legalidade ou ilegalidade desses sujeitos. Porém, poucas abordagens têm como problema focal esferas mais subjetivas de análise com o intuito de compreender de que maneira a existência desses indivíduos é afetada por essa experiência e, para além disso, quais são as novas formas de existir que lhes são ofertadas como possíveis. Nessa relação processual revelam-se muito mais do que efeitos/causas, evidenciando-se estruturas de grande profundidade a serem repensadas.

Um exemplo é a dinâmica estrutural perante a qual as relações de gênero se remodulam, revelando processos de extrema importância na reformulação desses sujeitos, tanto no país receptor como durante todo o processo de movimento. Outro aspecto é a questão do reconhecimento e da visibilidade no campo do político que esses sujeitos, homens e mulheres, passam a ter nos lugares que buscam estabilidade existencial. A vulnerabilidade dos corpos transitantes opera na esfera dos afetos e das subjetividades tanto quanto nos aspectos jurídicos e políticos, estando todas essas esferas circunscritas na precariedade do que se entende ser o outro, ser um estrangeiro ou estrangeira.

\section{Diáspora e Deslocamentos Conceituais do "outro"}

São várias as teorias que têm se dedicado a pautar e a reconhecer diferentes modelos diaspóricos, nos quais dois grandes grupos ganham proeminência: as diásporas persecutórias (ou de vítimas) e a comercial. 
As primeiras têm como casos mais notórios a diáspora dos armênios e a dos judeus; já as diásporas comerciais, imperiais, de assentamento e de trabalho, como defende Robin Cohen (1997), retiram do conceito de diáspora a sua vitimidade e, assim, modificam o seu gradiente de análise cultural, que se mobiliza por uma inserção desses grupos em sociedades hospedeiras com o objetivo de melhorar o nível de vida dos descendentes através da tentativa de obter ganhos financeiros, territoriais e comerciais. Seus maiores destaques são os casos das diásporas grega, chinesa, caribenha, indiana e mexicana. Novamente aqui, é possível perceber o caráter próprio de cada comunidade que se movimenta.

Diversos autores que se dedicam aos estudos diaspóricos abrem espaço, então, para uma valorização das culturas diaspóricas. Stuart Hall (2011) afirma que a história da humanidade é uma história de rupturas provocadas por contatos humanos de diferentes localidades e, por consequência, de distintas identidades. Para o sociólogo, esses processos ruptivos e disruptivos ocorrem em e provocam aquilo que ele chama de zonas de contato, espaços onde se confrontam e se relacionam diferentes realidades, ocasionando tensões na estrutura social que podem ser positivadas ou negativadas. As identidades, que se pretendem tão homogêneas e perfeitas, constituem-se a partir de um processo de assimetrias que, por vezes, podem se tornar violentas e brutais. E é a partir desses entrelaçamentos que surge, precisamente, aquilo que chamamos de cultura ou identidade e que, partindo desse paradigma de conflitos, se encontra bastante distante dos discursos difundidos acerca de uma autenticidade, seja ela étnica, política ou econômica. Nesse sentido, o suposto caráter homogêneo das culturas vem sendo questionado, mas ao mesmo tempo, é possível verificar uma certa sobreposição do fator cultural sobre os atores diaspóricos, como se a cultura fosse um elemento transnacional dominante e, de certa forma, mesmo independente dos indivíduos que a carregam e a (re)criam.

Os conceitos de cultura e identidade ganham centralidade nos estudos diaspóricos desse primeiro grupo, não só sobre as comunidades fortemente isoladas, mas também sobre aquelas plenamente integradas. 
As variáveis que são focadas nesses estudos culturais são: a dispersão; a "orientação em direção ao país natal", quer dizer, o cultivo de uma memória e de uma identidade que remetam ao país ou à comunidade de origem; $\mathrm{e}$ a "manutenção de uma fronteira" em relação ao país hospedeiro, ou seja, mesmo que exista um alto grau de integração ou mesmo um sentimento de pertença, ainda é possível distinguir elementos culturais que possibilitem o reconhecimento de uma única "comunidade transnacional" (BRUBAKER, 2005 , p. 6). Nesse aspecto, Homi Bhaba (2013) traz novamente para a questão o paradigma da homogeneidade, enfatizando que não existem tais entidades homogêneas, como nação, identidade, cultura ou mesmo comunidade transnacional: trata-se sempre de uma generalização metodológica e operacional que direciona o próprio reconhecimento, especialmente em uma identidade transterritorializada como é a da diáspora.

Stuart Hall (2011) também chama atenção para o fato de que esse reconhecimento não é sujeito a uma homogeneidade cultural, uma vez que o contato com a cultura hospedeira, e mesmo as variações que a própria experiência diaspórica proporciona, impedem uma similitude com a cultura "original". Trata-se, muito mais, de uma "identidade que vive com e através, não a despeito, da diferença; ou seja, por hibridização" (HALL, 1996, p. 75). Ainda que a autenticidade seja uma ideia perseguida ao longo da história das identidades, Hall (2011) aponta que, se assumirmos uma perspectiva crítica e analítica sobre o tema, torna-se inevitável inferi-lo partindo também do hibridismo, característica que pressupõe um cruzamento ou entrelaçamento de elementos variados na composição de todas as matrizes identitárias. Esses dois lugares - autenticidade e hibridismo - lançam-se a discussões acerca do tema do presente trabalho: a diáspora. Na inserção do grupo diaspórico na nova terra, seja no papel de imigrante, trabalhador transitório ou mesmo refugiado, é possível observar o surgimento de uma "família ampliada" nessa relação transnacional, com a formação de redes de solidariedade, de manutenção da cultura e da memória.

Hall (2011) propõe, dessa forma, que a diáspora não pode ser refletida a partir de uma concepção binária da diferença. Isso ocorre porque ela se 
constitui, primeiramente, como um processo que se dá a partir de mulheres e homens em uma situação bastante particular, que é a de exclusão. Esse horizonte de exclusão é construído e mediado pela ideia de que esse "um" é "outro". Em outras palavras, a relação de quem é de "fora" e quem é de "dentro" é que regula essas fronteiras de exclusão, ocasionando os contatos problemáticos que se estabelecem entre os diferentes homens e mulheres nesses contextos. E nesse lugar de binarismos estabelecidos por concepções científicas rígidas modernas eurocêntricas, a diáspora se propõe a enfrentar a problemáticas sobre alguns aspectos mais sensíveis e relevantes, não apenas do trânsito em si, mas sobre sentidos e vulnerabilidades que esse trânsito tem como desfecho para a questão de gênero, por exemplo. Nesse sentido, a reflexão pode ganhar ainda mais profundidade, por compreender que o significado de precariedade (BUTLER, 2018) atinge não apenas as noções de quão estrangeira é aquela comunidade de pessoas ou de quão aceita ela será, mas também diferentes sentidos de precariedade que são enfrentados por uma questão de gênero (homens diaspóricos, mulheres diaspóricas, lgbtq+ diaspóricos).

Essa dinâmica característica acarreta especificidades empíricas. Brent Hayes Edwards (2017) aponta que o termo diáspora precisa receber uma carga de análise sensível, diferente de outros aspectos utilizados pela historiografia mais tradicional, que se utiliza dos conceitos de imigração ou transnacionalidade usualmente. Isso porque a estrutura de processos diaspóricos envolve detalhes mais profundos, que pertencem à esfera do afeto, do reconhecimento social e do campo político. Dessa forma, a diáspora, diferente da imigração, que se constitui como uma estrutura binária de partida de um país e chegada a outro, modula-se principalmente por práticas e sentidos de ressignificação. Isso implica, segundo Jardim, Leal e Dimant (2015), repensar em três pontos fundamentais: 1) afirmação de um pertencimento; 2) legitimação e visibilidade; e, por fim 3) uma negociação política com o Estado e com a sociedade para a inclusão de novos horizontes de direitos no campo político. 
Nesse sentido, os processos diaspóricos não podem e nem devem ser entendidos a partir de uma relação causa/efeito, ou seja, atribuir o trânsito a uma motivação exclusiva ou rígida, que tem como desfecho o "direcionamento" de determinadas comunidades para um lugar específico, bem como o seu estabelecimento na sociedade de destino a partir de termos já acordados. Ou seja, não há uma razão econômica, ou política, ou social, ou étnica. Há um conjunto de elementos, algumas vezes todos os citados acima, que constituem uma situação de vulnerabilidade social e que motivam as movimentações humanas nessa busca abrupta por mudança. Edwards (2017) atribuiu esse movimento a um processo de desenraizamento e reconectividade. $O$ autor enxerga a diáspora a partir de algo como um conceito global e simples para se refletir um processo profundo: a Religação de Laços.

Com base nessa noção de novas perspectivas a serem estabelecidas e costuradas é que devem ser analisadas as estruturas complexas acerca desses trânsitos humanos. Sobre essa ideia de religação ou reestabelecimento de uma nova realidade a ser construída é que a antropóloga social e orientalista grega Eleni Sideri (2008) aponta que a diáspora se caracteriza por uma distinta forma de produzir sentidos de existir, a partir de uma nova ideia de relacionar-se com concepções de tempo-espaço. O que importa é a análise em que se produz essa diáspora no que diz respeito a conjuntura espaço temporal em que a mesma se desenvolve. Para ela, as diásporas produzem, evocam, moldam e são profundamente simbólicas. Sideri chama atenção para a concepção etimológica da palavra que foi atribuída para esses trânsitos. A palavra diáspora vem do grego "dia" que significa divisão ou dispersão e "spiro", que significa semear as sementes. Dessa forma, etimologicamente o termo "diáspora" se revela como uma condição de semeadura, partindo de um primeiro movimento de dispersão. Posteriormente, onde essas comunidades irão se estabelecer e as condições em que as mesmas serão recebidas é o lugar onde se confrontam os elementos apontados por Edwards - acerca das políticas, direitos, visibilidade e reconhecimento - confrontado pelas zonas de contato identitários citadas por Hall. 
A autora grega, assim como Edwards, reflete acerca das estruturas tradicionais construídas sob a égide da visão dicotômica e antiprocessual entre o passado e o futuro, ou seja, origem e destino, e destaca que esses aspectos talvez não sejam os mais relevantes para se pensar no desenvolvimento dessas comunidades em processo de readequação e reordenamento. Isso porque suas relações com as perspectivas de espaço-tempo se alteram e se remodulam a partir de uma nova realidade social, na qual esse grupo se depara com novas formas relacionais e necessita, muitas vezes, (re)criar essas noções de relação para a sua aceitação. Nesse sentido, pensar apenas o seu passado e o seu futuro não revelariam, propriamente, o caráter processual, ambivalente, conflituoso e até violento, como salientou Hall, que esses grupos em deslocamento passam.

Por esse aspecto de alteridade e percepção do outro, Sideri (2008) sugere que a diáspora pode ter uma implicação mais sensível no âmbito das acepções simbólicas, que serão fundamentais na construção das novas identidades ou as identidades híbridas - reconhecidas socialmente, já nesse momento, como distintas das "autênticas". Esse vínculo é espaço-temporalmente construído no campo político através das singularidades e assimetrias presentes e transitantes, onde o próprio entendimento do tempo e do espaço produzem e são produtores de identidades constantemente em deslocamento e reconfiguração. Ou seja, a diáspora produz agentes sociais que se confrontam como novos espaços e tempos e, dessa forma, modificam-se, ao passo que esses mesmos agentes sociais são modificadores ativos desses novos espaços receptores. Para a antropóloga social, a diáspora é uma nova forma de entender a relação que se tem com o espaço e o tempo, que está diretamente ligada à forma como esses dois conceitos se constituem e se imbricam nas identidades e as suas relações tripartidas de tempo: passado, presente e futuro.

A concepção do espaço no âmbito da historiografia é também ela uma das partes constitutivamente problemáticas nessa questão, do ponto de vista epistemológico do entendimento e uso do conceito de diáspora. Para a socióloga e geógrafa Doreen Massey (1994), o espaço é 
fundamentalmente produtor de três aspectos: primeiro, como relacional e produtor de relações; segundo, como esfera de multiplicidade e produtor de diferenças e, terceiro, como um processo e não como um sistema. Nesse sentido, indo ao encontro da abordagem de Sideri, o próprio espaço deve ser visto como uma categoria epistêmica, entendida não apenas como lugar de conflitos, mas como resultados dos mesmos. Massey pontua que o espaço, visto como processo em constante reformulação e transformação, é o que possibilita a reflexão do mesmo através das múltiplas trajetórias e possibilidades presentes nesse campo plural. Além disso, a teórica aponta que umas das relações fundamentais que devem ser percebidas no espaço geográfico, no que diz respeito a sua territorialidade e, como no caso das comunidades que se deslocam e que realocam em lugares distintos a sua (re)territorialidade, é assumir que todos os espaços são gendrados. O que perpassa, portanto, todo e qualquer movimento de diáspora, é a questão da distinção de gênero como fator fundamental para a constituição dessas novas identidades em seus países receptores.

Com a noção trazida até o presente momento, considera-se mais relevante levar-se em conta a noção processual do conceito de diáspora e menos causal ou seu efeito. James Clifford (1994) propunha que o processo diaspórico deve ser entendido como uma nova forma de consciência, onde a diferença se torna um elemento constitutivo da ligação política, cultural e social no novo território. Isso se dá, fundamentalmente, a partir de uma nova relação na própria existência desses sujeitos diaspóricos. Em Clifford, a diáspora é um processo de movimento coletivo. A coletividade é elemento constitutivo e imanente a esse movimento migratório, pois a construção de uma visão de mundo (MANNHEIM, 1974) que se rearticula para essa comunidade éamparada, fundamentalmente, na sociabilidade da mesma entre si e, posteriormente, na extensão desses e de novos laços relacionais com a sociedade que recebeu o grupo. Para Kaching Tölölyan (2012), nas comunidades diaspóricas há um encontro: as bases culturais antigas e novas se deparam e se conformam em uma identidade múltipla, balizada substancialmente pela diferença. Isso implica na aproximação de pressupostos mais profundos com implicações nas 
dinâmicas do campo do político, pois não são efêmeros e também não são transitórios. São estruturas que buscam se desenvolver a partir da fixação e dos sentidos de pertença de maneira mais estável, ao contrário das dinâmicas de refúgio ou exílio, que são mais viscerais, mais transitivas.

Tais considerações reforçam o fato de que a escrita da história desses grupos tem, com a ascensão do tema da diáspora nos estudos históricos, uma nova perspectiva de tendência transnacional e global. Isso porque as narrativas, que eram brutalmente ligadas às histórias nacionais dos países europeus, passam a ser concebidas em termos mais amplos, com foco no movimento dos povos e de suas culturas. Como Stuart Hall (2011, p. 35) exemplifica, narrativas transnacionais, como a do

Atlântico negro, proposta por Paul Gilroy, (são) potente(s) contranarrativa(s) à inserção discursiva do Caribe (e da África) nas histórias nacionais europeias, trazendo à tona as trocas laterais e as 'semelhanças familiares' na região como um todo que a 'história nacionalista obscurece' (GILROY, 1993).

No campo das narrativas, existe ainda a questão do próprio movimento diaspórico servir, em alguns casos, como o elemento aglutinador e definidor de uma identidade transnacional, e, principalmente, como elemento mobilizador de consciências e de lealdades. Como Marta Topel levanta, autores judeus, como George Steiner, questionam a centralidade que o Estado de Israel pretende se outorgar na estruturação da identidade cultural e espiritual judaica em detrimento de uma identidade diaspórica, de contornos universalistas (TOPEL, 2015, p. 333).

É, como fica evidente na caracterização de Topel, uma desconstrução da sionização da identidade diaspórica. Khaching Tölölyan, ele próprio possuidor de uma herança cultural armênia, percebe uma minoria dessa população diaspórica que têm na própria diáspora a sua base identitária, ainda que a grande maioria da população armênia que vive longe do Estado armênio demonstre uma ligação mais efêmera, aquilo que Herbert 
Gans chamou de "etnicidade simbólica" (GANS 1979 apud BRUBAKER, 2005, p. 13). É o que faz Brubaker, tendo em vista essas características da diáspora armênia: questionar se é metodologicamente correto tomar os armênios como uma população diaspórica por conta dessa minoria, enquanto a grande maioria da população de origem armênia pelo mundo já se encontra amplamente integrada, sem ligações com a língua ou a cultura armênias em sua identidade central. Frente a esse questionamento, é possível argumentar que nenhuma cultura é homogênea, e as culturas diaspóricas não seriam exceção. Se é possível identificar essas características e heranças culturais diaspóricas, ainda que, como Burbaker afirma, sejam alimentadas artificialmente com vistas a um projeto econômico ou político, não há razão para caracterizá-la de outra forma.

\section{Os Sujeitos diaspóricos gendrados: mobilização e mobilidade identitária}

Os questionamentos nas pesquisas mais recentes não se resumem a uma pretensa homogeneidade cultural e identitária do grupo diaspórico, mas também a uma invisibilização de elementos específicos nas construções narrativas globais. $O$ caso mais evidente desse processo é a invisibilização de gênero. Partindo desse resgate conceitual, pode-se retomar a questão que foi apontada acerca do paradigma da diferença e a sua importância na construção das identidades diaspóricas. O tema da mulher diaspórica pode ser visto como um dos eixos de estudo que mais vem subvertendo a antiga tendência a se pensar as identidades como homogêneas e dentro do paradigma da igualdade. Isso pode ser inferido, mais precisamente, a partir da clássica - porém ainda largamente negligenciada - abordagem trazida por Joan Scott (1992), onde a mesma questiona a forma como a História é pensada tradicionalmente. Para ela, interpretar os acontecimentos pela ótica da história das mulheres proporciona uma ampliação do campo de estudos, sendo pautado não apenas como um movimento ideológico, 
mas como um campo epistemológico definido, dando às mulheres o seu reconhecido protagonismo em determinada conjuntura.

O estudo da mulher em condição de diáspora se mostra um elemento pertinente para se refletir acerca dessas novas abordagens epistêmicas dentro do campo das Ciências Humanas. Nancy Green (2011) afirma que repensar a questão de gênero e das mulheres traria uma ruptura também relativa às convenções estabelecidas até agora no estudo de comunidades que se deslocam: qual a atuação dessas mulheres na sociedade na qual se estabelecem, se a imigração foi amplamente caracterizada e entendida como um fenômeno de chegada de indivíduos a outros países que contribuíram com a modernização, principalmente, pelo trabalho, que era exercido por homens?3 Quem foram, nesse sentido, os principais articuladores do desenvolvimento dessa comunidade na nova sociedade em que se estabeleceu? Essas perguntas são respondidas, segundo a autora, de maneira muito simples: figuras masculinas.

Partindo dessa perspectiva, percebe-se que a própria busca por uma condição de existência melhor foi balizada por saberes e possibilidades essencialmente masculinas e direcionadas para os homens. Questiona-se assim, portanto, a presença das mulheres nesse processo de trânsitos. No decurso do movimento dessas mulheres, como se constroem os hibridismos identitários apontados por Stuart Hall e Kaching Tölölyan? Em um estudo sobre a construção da feminilidade de judias estadunidenses, Sara Imhoff (2016) afirma que os padrões de feminilidade, por exemplo, são construídos e reconstruídos fortemente, a partir dos contextos em que se encontram. A feminilidade nunca está garantida, ela se altera e se reestrutura, conformando-se de acordo com o que a própria mulher reivindica ser feminino e também no que a sociedade pactua por feminilidade.

No caso da mulher diaspórica, a sua identidade irá se operar dentro dessa lógica. Seu núcleo identitário será alterado de duas maneiras: primeiro, por suas estruturas de "ser o outro" o estrangeiro e, ainda mais controversa,

3 Chama-se atenção aqui para os estudos acerca da mulher migrante no mundo do trabalho e o seu profundo processo de precarização. 
por sua condição de "ser a outra", ou seja, de ser mulher. A vulnerabilidade a que a mulher migrante é colocada é duplamente problemática, nesse sentido, pois a sua presença é abalada por dois eixos, o de ser estrangeira e o de ser mulher. Em outras palavras, o fator da diferença é reforçado na mulher diaspórica que tem toda a estrutura de reconhecimento afetada por este elemento, tanto no plano individual quanto no coletivo.

Mas se a homogeneidade dessas culturas originais, diaspóricas e transnacionais, é colocada naturalmente em xeque pelas pesquisas, seja por seu caráter híbrido, seja por sua variedade interna, ela passa a ser ainda mais questionada sob o prisma do que se vem a chamar de pós-modernidade. Assim como a própria natureza das identidades e das comunidades, as dinâmicas culturais que envolvem os grupos em diáspora têm vivenciado transformações profundas nas últimas décadas com o advento da globalização, da qual esses grupos são frutos e também agentes. Por um lado, no plano individual, é possível observar a diluição das identidades e das culturas, um processo que coloca todas as culturas e identidades à disposição do indivíduo para (re)conhecimento e valorização. Mas esse é um processo que também fomenta certa banalização das identidades culturais, um processo que, como Bauman descreve, leva à crise do multiculturalismo. Nas palavras do polonês,

\section{[...] enquanto o direito à diferença é garantido aos outros, o direito à indiferença (leia-se, evitar fazer julgamentos e agir de acordo com isso) é amplamente usurpado pelas mesmas pessoas que dão esse direito às outras. Quando a tolerância mútua se combina com a indiferença mútua, comunidades culturais podem viver na maior proximidade, mas raras vezes falam uma com a outra. (BAUMAN, 2013, p. 58)}

As tensões se aprofundam ainda mais quando essa falha da política multicultural se combina com um "sentir-se fora de lugar", com sensibilidades que fazem com que, em lugar da interação e do hibridismo apontado por Stuart Hall, ocorra um fechamento da comunidade, provocando ainda mais atritos entre as culturas. 
Em um trabalho mais recente, utilizando-se da Teoria Queer para interpretar essas visões culturalistas sobre os imigrantes indesejados, seus estereótipos e suas dinâmicas, Cynthia Weber (2016) reconhece uma semelhança entre as representações do imigrante indesejado com aquelas dos homossexuais pervertidos, representações que ensejam a ansiedade e o medo de ruptura da ordem ocidental. A ordem sexual e social seria perturbada pelos desejos desses elementos estranhos, que seriam reconhecidos, dentro do esquema cultural e civilizacional fechado "à la Huntington", como ameaças subdesenvolvidas em movimento, em direção ao corpo sadio da nação. Essa é a representação que fundamenta o fetiche por um muro que separe esses grupos do povo que quer se fechar à ameaça. Nesse mesmo sistema, a representação do terrorista da Al Qaeda se projeta como uma ameaça em movimento. Mas, ao contrário do imigrante indesejado, o terrorista não é considerado "subdesenvolvido", ou seja, inferior na escala civilizacional e, assim, indigno de convívio na sociedade desenvolvida, mas sim como "impossível de se desenvolver", ou seja, incapaz de ser salvo, de ser civilizado ou de se redimir.

Ambas as representações que Cynthia Weber aponta acabam por se fundir quando a figura do refugiado é colocada em pauta. Ao contrário do imigrante, que pode ser desejável ou indesejável, mas em geral é considerado assimilável, a representação do refugiado é associada a calamidades e crises que marcaram profundamente a história recente da Europa. A primeira grande crise de refugiados no século passado teve início em 1914, nos primeiros meses da Primeira Guerra Mundial, e resultou no deslocamento de milhões de pessoas por todo o continente. Peter Gatrell (1999) aponta que o despreparo para administrar esse fenômeno criou um imaginário de caos frente ao "problema dos refugiados", um imaginário alimentado pela imprensa e pelas políticas das grandes potências da época, que viam os seus exércitos deslocarem populações locais e acabavam recebendo, como refluxo, esses contingentes populacionais. Belgas na França, sérvios na Áustria e na Rússia, boêmios na Itália, armênios e judeus para onde conseguissem fugir, além das grandes massas 
de deslocamento interno nos países provocaram transtornos financeiros, burocráticos e sociais que tiveram longo alcance. A incapacidade dos Estados transferiu o problema para a caridade, para os vários comitês e instituições que passaram a olhar pelos refugiados.

O próprio termo, refugiado, passou a ser utilizado, como sublinha Hannah Arendt (1999), na esperança de que essas organizações dessem atenção a eles e de que asilos fossem concedidos.

Mas o direito a asilo tinha perdido sua validade por duas razões: em primeiro lugar, havia refugiados demais, e em segundo lugar, eles não podiam ser considerados refugiados propriamente porque não eram perseguidos. A solução da caridade também não funcionava, pois não tinha significação jurídica. (HEUER, 2006, p. 3)

A Justiça, portanto, não tinha solução para o problema. O apontamento de Heuer torna claro apenas mais uma vez que a questão dos diaspóricos e diaspóricas ou, como Hannah Arendt definiu em seu texto, os refugiados, envolvem uma questão de grande subjetividade e que se tornam a problemática mais sensível do que as imigrações que envolvem, como apontado mais acima do texto, contextos de assimilação facilitada. Tais subjetividades estão no entrecruzamento das questões burocrática, política e identitária. Nesse sentido, Gayatri Spivak (2010) aponta que no que se refere ao estrangeiro, sobretudo aqueles que se encontram em condição diaspórica, buscando alguma estabilidade mais concreta no país que se alocam, a subalternidade é um elemento que percorre todas as estruturas físicas e mentais do indivíduo, sendo estabelecida pela sua diferença para com o outro. Em seu livro clássico Can the Subaltern Speak (2010), a autora aponta que os sujeitos e sujeitas subalternos não tiveram ainda suas histórias contadas, sendo suas narrativas apenas aquilo que ela chama de fragmento interpretativo dos intelectuais ocidentais. Nessa perspectiva, Spivak propõe a reflexão acerca do que é propriamente ser 
um estrangeiro, ou seja, em quais sentidos esse estrangeirismo pode ser sentido e de que maneiras ele se expressa socialmente. Um ponto crucial para a indiana nessa questão é o olhar de gênero. Para ela, a mulher encontra-se em uma condição de "dupla subalternidade", pois, desenvolve a sua precariedade tanto no ser estrangeiro quanto no ser mulher. Ou seja, a esfera da vulnerabilidade para a mulher diaspórica é ampliada em outros aspectos que o homem diaspórico não sentirá.

O fim da guerra não foi o fim da crise, uma vez que as políticas de repatriamento eram diferentes de país para país, as novas fronteiras estabelecidas e os novos Estados criados modificavam também as ideias de identidade e de pertença a uma nação, e os conflitos remanescentes nas fronteiras, naquilo que Jay Winter (2018) chamou de segunda primeira guerra mundial, impediam muitos refugiados de se deslocarem. Em uma perspectiva cultural, o imaginário que resulta dessas experiências diaspóricas forçadas moldam, em grande medida, o próprio imaginário europeu. A repetição da crise apenas 30 anos depois e mesmo na atual crise dos refugiados reforçaram essas representações de "estranhos à nossa porta", que, como Bauman (2017) descreve, é capaz de provocar um "pânico moral" e desorientar os sentidos políticos dos europeus, levando à aceitação de discursos de ódio e nacionalistas, criando brechas morais que são aproveitadas por populistas e que fazem desmoronar qualquer estrutura humanitária. Em um exemplo apontado por Vlasta Jalusic (2017), quando a "onda de migrantes e refugiados" bateu às portas da Eslovênia em 2015, não foram as histórias e narrativas odisseicas ou as razões da crise humanitária gerada pelos conflitos na Síria e crises no norte da África que tomaram a opinião pública no país, mas a condição de vítima que toda essa situação lançava a Eslovênia, em um processo que conduz à desumanização dos refugiados. É, ao fim, um conflito de representações e imaginários, mas também um processo de violência. Um processo que, não raro, coloca esses despossuídos no centro da pauta de um Estado de exceção, nos moldes de Agamben (2004), e de uma Necropolítica, nos moldes de Mbembe (2018). 
Esse aspecto das pesquisas sobre as diásporas chama atenção para a segunda linha de pesquisas, para além das pesquisas culturalistas (que são maioria). Nesse campo, os estudos são mais voltados ao campo da História Política e Filosófica. Centrada especialmente nos casos dos refugiados, mas não só, ela parte de uma questão essencial: a humanidade e a dignidade mesmas dos indivíduos em trânsito. Essa percepção da questão dos refugiados tem uma historicidade própria no século XX, como a carta que Hannah Arendt troca com Eric Cohn-Bendit em 1940 exemplifica:

Todas as políticas voltadas às minorias, não apenas aquelas relativas aos judeus, estão condenadas ao fracasso como resultado da continuada existência da soberania estatal. [...] com o começo das migrações em massa da Rússia, em 1923/4, [...] podemos ver a emergência de uma classe completamente nova de pessoas: o apátrida (ARENDT, 2000, p. 231).

Caracterizado como o produto mais significativo da história europeia recente, o pária se torna um elemento típico dessa era dos Estados nacionais, mas também pouco compreendido. Os deslocamentos transnacionais que se verificaram na Europa da primeira metade do século $\mathrm{XX}$ e as ondas transcontinentais da segunda metade fazem com que as figuras do apátrida e do refugiado sejam, na verdade, figuras de párias. Eles se tornam elementos perturbadores da ordem burocrática e social dos velhos Estados europeus, passando a ser objeto de reflexão historiográfica, política e sociológica. Aqui, não são mais as representações, as identidades, as culturas ou as narrativas odisseicas que são foco de análises, mas sim as formas de recepção desses elementos, as violências e repressões que cercam as suas condições política e jurídica, além, claro, da reflexão sobre a sua condição humana em seu não lugar burocrático. Se é possível falarmos do estado de exceção que, nas palavras de Walter Benjamin, se tornou a regra de nossa história recente (BENJAMIN, 2013, 
p. 13), os apátridas e refugiados são, a um só tempo, seus produtos mais antigos, suas evidências mais claras e suas cobaias mais úteis.

Isso porque o apátrida e o refugiado estão em um não lugar em termos jurídicos. Não têm documentos que o permitam ficar, não têm lugar para onde voltar, não têm espaços para onde seguir. Presos em um nebuloso paradoxo, eles não dispõem de nada além de seu corpo e de sua memória, e um corpo que está completamente à mercê, pois nem mesmo um Estado que o reclame existe. Didi-Huberman descreve esse não espaço como "algum lugar entre o que Adorno chamou a 'vida mutilada' (ali onde cruelmente falta-nos contato) e a possibilidade de uma vida do pensamento (onde mesmo no olhar a distância nos solicita)" (DIDI-HUBERMAN, 2016, p. 16). Ai Weiwei (2019) destacou a condição "à deriva" desses elementos, não apenas ao ilustrar as travessias por mar que vêm caracterizando as ondas de refugiados que tomam boa parte do mundo, especialmente na Europa e na Ásia, mas também as vidas à deriva que advêm desse trajeto, apartada de suas origens e aportadas em um não lugar. Por fim, Bertold Brecht assimilou essa condição de forma irônica quando ele mesmo, um exilado do nazismo, escreveu que

o passaporte é a parte mais nobre no homem [na mulher]. Um passaporte não se fabrica tão simplesmente, como se fabrica um homem [uma mulher]. Pode-se fazer um homem [uma mulher] não importa onde, da maneira mais irrefletida do mundo, sem motivo razoável; um passaporte, nunca" (BRECHT, 1972, p. 9 apud DIDI-HUBERMAN, 42, 2016).

As corporalidades evidenciadas nesses apontamentos estão à mercê também em um processo que Beatriz Preciado (2003) chamou, em seu texto "Multidões Queer: notas para uma política dos anormais", de desterritorialização do corpo, não apenas do espaço. O corpo diaspórico, que transita por um lugar de mudança material, é também um corpo em alteração, compreendendo a dimensão de gênero e a esfera das emoções ou estruturas mentais que organizam esses corpos. Em outras palavras, o corpo transitante 
é também um corpo que subverte a ordem das normas que organizam a sua própria corporalidade em estruturas de heteronormatividade, cuja resistência identitária se dá não apenas nos aspectos mais visíveis ou palpáveis, naquilo que se refere a costumes ou saberes compartilhados corriqueiramente e que dão sentido àquela comunidade no país receptor. Trata-se também de uma resistência ao próprio sentido que a heteronormatividade e a dominação masculina produzem nesses corpos. Esse processo torna ainda mais complexa a relação do corpo com essa nova experiência que é o ser estrangeiro em um lugar indefinido ou um não lugar. Por conta dessa condição de precariedade em sua superfície corporal, a experiência da diáspora recebe outros olhares mais sensíveis e subjetivos, para além de suas faces de hibridismo e de remodulação cultural. Trata-se de uma remodulação de existência.

Essa condição específica dos refugiados, apátridas e exilados impõe uma reflexão sobre a própria natureza do Estado nacional, sobre as possibilidades que instituições internacionais podem oferecer a essas pessoas e sobre as possíveis soluções a sua não existência jurídica. Essas reflexões se desenvolvem em torno daquilo que Hannah Arendt (1999) chamou de “direito a ter direitos". É, na perspectiva da obra arendtiana, que é voltada à ação política, uma chamada para que os então párias se tornem atores políticos reais, que a sua posição desterritorializada se torne uma posição em um terreno político. Ou, como Helgard Mahrd (2017) assinala, ganhar uma espacialidade que os permita ser e aparecer.

\section{Considerações Finais}

A busca por uma solução deve passar, necessariamente, pelo rompimento com o enquadramento político e jurídico do Estado Nação. Mas qual a via para isso? Como Seyla Benhabib (2004) demonstra, o apelo às instâncias internacionais, como a própria ONU, não geram resultado efetivo porque essas mesmas instâncias não ultrapassam a esfera do Estado nacional. Ela cita a Declaração dos Direitos Humanos, de 1948, que reconhece o direito de emigrar, quer dizer, de transpor fronteiras, mas não garante o de imigrar, 
ou seja, o de entrar em um país, pois isso feriria o princípio de soberania nacional. Não existe qualquer tipo de obrigação dos Estados frente a refugiados, exilados ou pedidos de asilo. Enquanto a ONU e outras instituições internacionais, como a OTAN, podem justificadamente interferir na soberania nacional em casos de crimes contra a humanidade, crimes de guerra ou em intervenções humanitárias, elas são imobilizadas em casos de massas diaspóricas e de refugiados. Essa lógica está baseada na ideia de uma arena pública internacional baseada em Vestefália, ou seja, na ideia de que os membros soberanos dessa comunidade são os Estados nacionais, não os corpos individuais que compõem esses Estados. Não existem leis ou direitos para os indivíduos, portanto, que não estejam também atrelados aos Estados.

No momento em que um refugiado deixa suas bordas ele está por sua conta e risco, em um não lugar, e, assim, sem direitos. Benhabib (2004), tomando a ideia arendtiana de pensar um sistema onde os indivíduos tenham permanentemente direito a ter direitos, propõe um regime internacional de direitos humanos, uma teoria de justiça cosmopolita que não se restrinja a questões sobre distribuição de recursos e direitos, como o sistema atual, mas que se ocupe também do justo pertencimento dos indivíduos a essa comunidade. A proposta de uma justiça cosmopolita desterritorializa o acesso ao direito, proporcionando uma cidadania cosmopolita a todos e, assim, direito a todos. Mas como proceder com isso quando as próprias organizações internacionais dependem largamente dos recursos e da legitimidade que é dada por Estados nacionais?

Wolfgang Heuer reconhece esse problema e vai além, indicando que

o maior problema para os países que recebem apátridas (ou refugiados) consiste na 'disseminação da ilegalidade', quer dizer, nas ações ilegais em relação àqueles que vivem em condições essencialmente ilegais. O fato da polícia, e não da lei, ser responsável por eles altera o próprio caráter da polícia. Ultrapassando os limites como uma agência executiva da lei e se tornando ela mesma, ao mesmo tempo, legisladora e 
executora, a polícia governa sobre um povo, se torna sujeito, um Estado dentro do Estado, o rei de um reino. Ao construir campos de concentração a polícia adquire até mesmo um território (HEUER, 2016, p. 4).

Isso abre para o historiador alemão duas questões: a primeira é a da ação política dos refugiados, dos apátridas, que precisam tomar o campo público, ganhar visibilidade não como vítimas, mas como indivíduos conscientes e politicamente ativos, em sua busca por reconhecimento. A segunda questão, que segue a primeira, é que essa busca por reconhecimento precisa ser guiada em direção à erosão do sistema de Estados nacionais. Apenas em um sistema que transcenda as fronteiras do direito é que o refugiado pode ter uma existência política e social garantida, desligada do reino da ilegalidade e do estado de exceção que ele impele.

A proposta que surge das pesquisas e reflexões de Wolfgang Heuer vai ao encontro da justiça cosmopolita de Benhabib, mas acrescenta três aspectos. O primeiro, já comentado, é a ação pública dos refugiados, o segundo é a conscientização e a aceitação de uma responsabilidade humana por parte da população receptora dos refugiados. O terceiro aspecto é a busca por sistemas federalistas que transcendam a lógica do Estado nacional e que, se não garantem o direito a ter direito dos apátridas, ao menos "reduz significativamente a vulnerabilidade das minorias e a estrutura excludente e confrontante da soberania" (HEUER, 2016, p. 10). Esses sistemas federalistas de compartilhamento e de ação conjunta precisam, além disso, deixar de ser formalidades burocráticas ou diplomáticas e precisam se tornar estruturas de ação e de pensamento. Ao criar um novo espaço de poder a partir de ações compartilhadas, o federalismo cria poder e liberdade, estabilizando a ambos.

Percebe-se, por fim, que os estudos historiográficos e políticos sobre as diásporas, em suas múltiplas acepções, movimentam subjetividades e emocionalidades que ultrapassam, em muito, as questões das representações e das identidades. Passam pela corrente majoritária culturalista 
e também ultrapassam as questões políticas e institucionais. Suas reais atualidade e urgência estão no fato da questão dos imigrantes e dos refugiados ser um "desafio político-existencial". Isso porque ela diz respeito ao viver junto, ao agir junto. Um mundo globalizado, como o que vivemos, não é necessariamente um mundo compartilhado (HEUER, 2016), e as distâncias burocráticas entre os indivíduos podem ser as maiores divisoras dos povos e das culturas. Tais distâncias cobrem todo o globo, mas se mostram de forma mais clara no não lugar que as diásporas podem acabar por produzir. É esse não lugar, conjugado ao espaço do político, o espaço-entre (Inzwischen) a ser criado na vivência pública dos atores diaspóricos, que reserva a mudança de paradigma nos estudos e reflexões sobre o tema da Diáspora, compreendendo o reconhecimento de suas existências e de suas corporalidades em um aspecto muito mais amplo daqueles abordados nas teorias tradicionais até então. Subvertendo a ideia da assimilação cultural, os diaspóricos desenvolvem uma nova forma de experiência que envolve não apenas a sua aceitação, mas também uma nova forma de compreender as suas corporalidades, as suas visibilidades, precisamente onde as suas presenças desafiadoras incitam novas formas de reconhecimento social e de relação com a ideia da diferença.

\section{Referências}

AGAMBEN, Giorgio. Estado de Exceção. São Paulo: Boitempo, 2004.

ARENDT, Hannah. Origens do Totalitarismo. São Paulo: Cia das Letras, 1999. ARENDT, Hannah. Vor Antisemitismus ist man nur noch auf dem Monde sicher. München: 2000.

BAUMAN, Zygmunt. A Cultura no Mundo Líquido. Rio de Janeiro: Zahar, 2013.

BAUMAN, Zygmunt. Estranhos à nossa Porta. Rio de Janeiro: Zahar, 2017. https://doi.org/10.12957/rmi.2016.31471

BENHABIB, Seyla. The Rights of Others: Aliens, Residents and Citzens. Cambridge: Cambridge Univ. Press, 2004.

BENJAMIN, Walter. O Anjo da História. Belo Horizonte: Autêntica, 2013. 
BHABHA, Homi. O Local da Cultura. Belo Horizonte: Ed. UFMG, 2013. BRECHT, Bertold. Dialogues d'exilés (1940-1941). Paris: L'Arche, 1972.

BRUBAKER, Rogers. The 'Diaspora' Diaspora. Ethnic and Racial Studies, v. 28, n. 1, p. 1-19, jan. 2005. https://doi.org/10.1080/0141987042000289997

BUTLER, Judith. Corpos em Aliança e a Política das Ruas. Rio de Janeiro: Civilização Brasileira, 2018.

CLIFFORD, James. Diasporas. Cultural Anthropology, Washington, v. 9, n. 3, 1994. p. 302-338.

CLIFFORD, James. Diasporas. Cultural Anthropology, Washington, v. 9, n. 3, ago. 1994. p. 302-338.

COHEN, Robin. Global Diasporas - an Introduction. London: Routledge, 1997.

DIDI-HUBERMAN, Georges. Quando as imagens tomam posição. Belo Horizonte: EdUFMG, 2017.

EDWARDS, Brent Hayes. Os usos da diáspora. Translatio, Porto Alegre, n. 13, p. 40-71, jun. 2017

GATRELL, Peter. A whole Empire walking: Refugees in Russia during World War I. London: Bloomington, 1999.

https://doi.org/10.1086/ahr/105.5.1837

GILROY, Paul. The Black Atlantic. London: Verso, 1993.

GREEN, Nancy L. Mudando Paradigmas em estudos de Migração de Homens para Mulheres Para Gênero. In: PEDRO, Joana et al. (org.). Diásporas, Mobilidades e Migrações. Florianópolis: Editora Mulheres, 2011.

HALL, Stuart. Da Diáspora: Identidades e Mediações Culturais. Belo Horizonte: EdUFMG, 2011.

HALL, Stuart. Identidade Cultural e Diáspora. Revista do Patrimônio Histórico e Artístico Nacional, n. 24, p. 68-75,1996.

HEUER, Wolfgang. La Politisation des Minorités. Palestra apresentada por ocasião do evento 1906-2006: Cent ans après la naissance d'Hannah Arendt. Paris, 16-18 nov. 2006. Mimeo.

HEUER, Wolfgang. Refugiados e Estado Nacional na Crítica de Hannah Arendt. Palestra apresentada por ocasião do evento Migração e Direitos Humanos. São Paulo, 9-10 nov. 2016. Mimeo. 
HARAWAY, Donna. Saberes localizados: a questão da ciência para o feminismo e o privilégio da perspectiva parcial. Cadernos Pagu, v. 5, p. 7-41, 2009. HEYWOOD, Linda. Diáspora Negra no Brasil. São Paulo: Contexto, 2008. HUNTINGTON, Samuel. Choque de Civilizações. São Paulo: Objetiva, 1997. IMHOFF, Sarah. The Myth of American Jewish Feminization. Jewish Social Studies: History, Culture, Society, v. 21, n. 3, p. 126-152, 2016. https://doi. org/10.2979/jewisocistud.21.3.05

JALUSIC, Vlasta. Refugees Today: superflousness and humanitarianism. Estudos Ibero-americanos, Porto Alegre, v. 43, n. 3, p. 524-534, nov. 2017. https://doi. org/10.15448/1980-864x.2017.3.26139

JARDIM, Denise F; LEAL, João; DIMANT, Mauricio. Diásporas. Horizontes Antropológicos, Porto Alegre, n. 43, v. 21, p. 9-18, jan./jun. 2015. https://doi. org/10.1590/s0104-71832015000100001

MAHRD, Helgard. Repensando nossa Crise dos Refugiados com Hannah Arendt. Estudos Ibero-americanos, Porto Alegre, n.3, v. 43, p. 535-547, nov. 2017. MANNHEIM, Karl. Sociologia da Cultura. São Paulo: Perspectiva, 1974.

MASSEY, Doreen. Space, Place and Gender. Cambridge: Polity, 1994.

MBEMBE, Achille. Necropolítica. São Paulo: N-1, 2018.

MEAD, Margareth. National Character and the Science of Anthropology. In: LIPSET, S.; LOWENTHAL, L. (org.). Culture and Social Character. New York: Free Press, 1961. p. 15-26.

PRECIADO, Beatriz. Multidões Queer: notas para uma política dos anormais. Estudos Feministas, Florianópolis, v. 19, n. 1, p. 11-20, jan. abr. 2011. https:// doi.org/10.1590/s0104-026×2011000100002

SCOTT, Joan W. História das Mulheres. In: BURKE, Peter (org.). A Escrita da História. São Paulo: UNESP, 1992. p. 63-96.

SIDERI, Eleni. The Diaspora of the Term Diaspora: A Working- Paper of a Definition. Transtext(e)s Transcultures, n 4, p. 32-47, 2008. https://doi. org/10.4000/transtexts.247

SPIVAK, Gayatri. Pode o Subalterno falar? Belo Horizonte: EdUFMG, 2010.

TÖLÖLYAN, Khachig. Estudos da Diáspora: Passado, Presente, Promessa. Translatio, Porto Alegre, n. 13, p. 22-39, jun. 2017. 
TÖLÖLYAN, Khachig. Diaspora studies: past, present and promise (Working Papers). Oxford: International Migration Institute, 2012.

TOPEL, Marta. Terra Prometida, Exílio e Diáspora. Horizontes Antropológicos, Porto Alegre, v. 21, n. 43, p. 331-352, jan./jun. 2015. https://doi.org/10.1590/ s0104-71832015000100013

WEBER, Cynthia. Queer International Relations. Oxford: Oxford Unipress, 2016. WEIWEI, Ai. Raiz Weiwei. São Paulo: Ubu, 2019.

WINTER, Jay. Remembering War: The Great War between Memory and History in the Twentieth Century. Yale Univ. Press, 2006.

WINTER, Jay. The Second Great War, 1917-1923. Revista Universitaria de Historia Militar, Madrid, v. 7, n. 14, 2018. 160-179.

ZLOTNIK, Hania. Past Trends in International Migration and their Implications for Future Prospects. In: SIDDIQUE, M.A.B. (ed.). International Migration into the Twenty-first Century. Boston: E. Elgar, 2001. p. 227-262.

\section{Endereço Postal}

Universidade Federal do Rio de Janeiro

Núcleo Interdisciplinar de Estudos Judaicos

Largo de São Francisco, 01

Sala 427, Rio de Janeiro - RJ

CEP: 20051-070 